\title{
Age Differences in the Use of Language Learning Strategies
}

\author{
Mei-Ling Chen ${ }^{1}$ \\ ${ }^{1}$ Department of Applied English, Hung-Kuang University, Taiwan \\ Correspondence: Mei-Ling Chen, 34 Chung-Chie Rd., Sha Lu 443, Taiwan. Tel: 886-4-2631-8652. E-mail: \\ mlchen@hk.edu.tw
}

Received: February 26, 2013 Accepted: November 11, 2013 Online Published: January 6, 2014

doi:10.5539/elt.v7n2p144 URL: http://dx.doi.org/10.5539/elt.v7n2p144

\begin{abstract}
The purpose of the study was to investigate language learning strategies used by English as a Foreign Language (EFL) learners at different educational levels and explored the influence of age on the use of language learning strategies. A total of 1,023 students participated in the study. Out of the participants, there were 250 primary students (aged 10-12), 245 junior high school students (aged 13-15), 249 senior high school students (aged 16-18), and 279 tertiary students (aged 20-22). The instrument for data collection was the Strategy Inventory for Language Learning (SILL). Results showed that statistically significant relationships existed between different age groups and the use of memory strategies, compensation strategies, metacognitive strategies, and affective strategies. Specifically, secondary and tertiary students reported using compensation strategies more frequently than primary students $(\mathrm{p}=.000)$. Tertiary students used social and affective strategies more frequently than did other age groups. The result indicated that age increase is likely to encourage learners to use strategies with more emphasis on the social and functional strategies. Implications are that it is critical for teachers to be more aware of the differences in their students and adjust their teaching practices to meet the developmental needs of students.
\end{abstract}

Keywords: language learning strategies, age, second language acquisition

\section{Introduction}

In Taiwan English is used to pass the entrance examinations of well-known senior high schools, colleges, and universities. English instruction has a strong basis in teacher-centered and exam-oriented classes, with teacher delivery of lectures as the focus of instruction (Huang, 1989; Lo, 1996). Learners' individual differences, such as age and learning strategies uses, have been ignored as a part of the instructional process. Many studies revealed that individual differences play an important role in second or foreign language acquisition (Ehrman, 1990; Galbraith \& Gardner, 1988; Oxford, 1992; Oxford \& Ehrman, 1993; Scarcella \& Oxford, 1992; Skehan, 1989). Among these individual-difference variables, "language learning strategies appear to be among the most important variables influencing performance in a second language" (Oxford, 1989, p. 21).

Several studies have investigated language learning strategies used by English as a Foreign Language (EFL) learners (Abdolmehdi \& Mohammad, 2005; Chang et al., 2008; Huang, 1997; Lai, 2009; Lan \& Oxford, 2003; Li \& Qin, 2006; Yang, 1992). Nevertheless, few studies dedicated specifically to the age factor on the use of language learning strategies. Thus, there is a need for further exploration into the relationship between age and learning strategy use in an English as a Foreign Language (EFL) setting.

The purpose of the study was to investigate language learning strategies used by English as a Foreign Language (EFL) learners at different educational levels in Taiwan and explored the influence of age on language learning strategy use. Towards this end, two research questions were posed:

1) What are the differences in the frequency of language learning strategy used by English as a Foreign Language (EFL) learners at four educational levels?

2) Is there a relationship between age groups and learning strategy use?

\section{Literature Review}

\subsection{Language Learning Strategies}

Since the 1970s, researchers made efforts to investigate successful language learners' learning strategies and classify learning patterns from those successful learners. There are various classifications of language learning 
strategies. Each type of classification has its own characteristics and provides researchers with insights into the grouping of language learning strategies.

Naiman et al. (1978) interviewed good language learners and proposed five primary strategy categories, and a number of secondary strategy categories. The primary strategies refer to those strategies which were commonly used by all good language learners interviewed, and the secondary strategies refer to those strategies which were used only by some of the good learners.

The primary strategy categories include: (a) an active task approach, (b) realization of language as a system, (c) realization of language as a means of communication and interaction, (d) management of affective demands, and (e) monitoring of second language performance. An active task approach includes responding positive to learning opportunity or seeking and exploiting learning environment, adding related language learning activities to regular classroom program, and practicing. Realization of language as a system encompasses analyzing individual problems, making first language and second language comparisons, analyzing target language to make inferences, and making use of fact that language is a system. Realization of language as a means of communication and interaction is composed of emphasizing fluency over accuracy, and seeking communicative situations with L2 speakers. Management of affective demands consists of finding socio-cultural meanings, and coping with affective demands in learning. Monitoring L2 performance refers to constantly revising L2 system by testing inferences and asking L2 native speakers for feedback.

According to Bialystock (1978), there are four types of learning strategies, including inferencing, monitoring, formal practicing, and function practicing. Rubin (1981) classified the learning strategies into two categories: direct strategies and indirect strategies. Direct strategies refer to strategies that directly affected learning, including clarification/verification, monitoring, memorization, guessing/ inductive reasoning, deductive reasoning, and practice. Indirect strategies refer to strategies that contributed indirectly to learning, including creating practicing opportunities and using production tricks.

There are three categories of strategies used by learners: cognitive, metacognitive and affective-social strategies (Brown \& Palinscar, 1982; O'Malley \& Chamot, 1985). Cognitive strategies refer to manipulating or transforming the learning materials directly in specific learning tasks, such as repetition, translation, grouping, note-taking, deduction, recombination, imagery, auditory representation, keyword, contextualization, elaboration, transfer, and inferencing (O'Malley \& Chamot, 1985). Metacognitive strategies refer to an overall control over the learning process, such as advanced organizers, direct attention, selective attention, self-management, planning, reasoning, monitoring, and self-evaluation. Affective-social strategies mean the way in which learners cope with their affective demands and social interaction with others, such as cooperation with peers and questions for clarification.

In the early nineties, Oxford (1990) synthesized most strategies into a system. Her system is presently the most popular and widely used classification to analyze language learning strategies throughout the world. The new system of language learning strategies included two major categories: direct strategies and indirect strategies. Although there were different focuses in each category, these two classes compensated with each other and supported each other in helping learners to learn a target language (Oxford, 1990). Direct strategies are sub-divided into memory, cognitive, and compensation strategies. Indirect strategies are sub-divided into metacognitive, affective, and social strategies.

Direct strategies required mental processing of the language and involved the language directly. Memory strategies are ways to help learners enter information into memory and retrieve new information, such as grouping, imagery, and structured review. Cognitive strategies are ways to manipulate the language reception and production of meaning, such as scanning, analyzing, and summarizing. Compensation strategies are ways to help learners overcoming limitations in existing knowledge, such as guessing wisely in reading and listening, and using gestures in speaking and synonym in writing.

Indirect strategies supported language learning, but they did not involve using the language directly. Metacognitive strategies are ways to help learners organize and evaluate learning, such as concentration on learning, planning and organizing for learning tasks, and evaluation of learning. Affective strategies are ways to help learners manage emotions and attitudes, such as self-encouragement, anxiety reduction, and discussing feelings with others. Social strategies are for learning with others, such as clarification, communication with native speakers or higher proficiency learners, and increasing knowledge of the target language culture. This study will employ Oxford's (1990) language learning strategy classification system. 


\subsection{Influence of Age on Language Learning Strategies}

A few studies have investigated age/course level and language learning strategies in Western countries (Devlin, 1996; Lee \& Oxford, 2008; Oxford, 1990; Oxford \& Nyikos, 1989). Oxford and Nyikos (1989) explored factors affecting choice of language learning strategies by university students. The participants were 1, 200 foreign language students in one university in the United States. Oxford and Nyikos discovered that students who had studied the language for more than five years used functional practice strategies or communicative strategies more frequently than less experienced students; students who had spent more than four years studying a foreign language used conversational input elicitation strategies more often than less experienced students.

Oxford (1990) stated that students of different ages and learning stage of second language employed somewhat different strategies; older or more advanced students used certain strategies more frequently than did younger or less advanced students. Devlin (1996) compared the learning and study strategies employed by mature age (defined as 23 years of age or more) and younger university students (defined as 22 years of age or less) as measured in the Learning and Study Strategies Inventory (LASSI). The findings indicated that mature age students reported themselves employing metacognative strategy more efficiently than their younger counterparts. Lee \& Oxford (2008) indicated that young learners tended to use social strategies like discussing with and asking help from others more than other types of strategies. In contrast, adult learners have shown high use of metacognitive strategies such as planning, organizing, and evaluating their own Second Language (L2) learning.

\section{Method}

\subsection{Participants}

This study included 1,023 participants from four levels of education- elementary, junior, senior high school and university. It is given that stage of schooling generally correlates with age. Out of the participants, there were 249 primary school students (aged 10-12), 245 junior high school students (aged 13-15), 249 senior high school students (aged 16-18), and 279 tertiary students (aged 20-22). The primary students were selected from two elementary schools, one located in southern Taiwan and the other one in the north of Taiwan. The secondary students were selected from four middle schools, two from the south and two from the north. All the tertiary students were enrolled at one university in Central Taiwan. Permission to administer the instrument was obtained with the aid of English teachers. Consent forms were signed by parents/guardians and participants. Of those, 1,040 students had parental permissions and participated in the study. Of the 1,040 respondents, 1,023 respondents' responses were valid for statistical analysis.

\subsection{Instrumentation}

The Strategy Inventory for Language Learning (SILL), EFL/ESL 7.0 version, (Oxford, 1990) was used to investigate the frequency of the participants' use of language learning strategies. The Strategy Inventory for Language Learning (SILL) is "perhaps the most comprehensive classification of learning strategies to date" (Ellis, 1994, p. 539). Yang (1992), Liao (2000), and Liu (2004) translated Oxford's SILL into Chinese. The internal-consistency reliability of Yang's (1992) Chinese SILL was .94, Liao's (2000) Chinese SILL was .96, and Liu's (2004) Chinese SILL was .94. In other words, the SILL has been shown to be "psychometrically stronger than most other self-report learning strategy surveys" (Oxford, 1987, p. 39).

This instrument contains six subscales: (1) memory strategies, (2) cognitive strategies, (3) compensation strategies, (4) metacognitive strategies, (5) social strategies, and (6) affective strategies. The instrument was conducted in Mandarin Chinese, the native language of the participants, to minimize the interference of their English abilities and help them understand each statement more easily. The participants were asked to read and respond to each statement. Item responses follow a five-point Likert-scale which ranges from "never or almost never true of me" (point 1), "usually not true of me" (point 2), "somewhat true of me" (point 3), "usually true of me" (point 4), to "always or almost true of me" (point 5). In addition, each participant was asked to self-report his/her grade level, age and gender on the Strategy Inventory for Language Learning (SILL).

\section{Results and Discussion}

\subsection{Research Question 1}

As Table 1 represented, the strategies used most frequently by elementary school students were metacognitive strategies $(M=2.93)$, followed by memory strategies $(M=2.80)$, social strategies $(M=2.74)$, affective strategies $(M=2.69)$, cognitive strategies $(M=2.68)$ and compensation strategies $(M=2.60)$. Junior high school students indicated a preference for compensation strategies $(\mathrm{M}=2.96)$, followed by memory strategies $(\mathrm{M}=$ 2.68), social strategies $(M=2.68)$, metacognitive strategies $(M=2.68)$, cognitive strategies $(M=2.67)$ and affective strategies $(\mathrm{M}=2.50)$. The most used strategies by senior high school students were compensation 
strategies $(M=2.96)$, followed by metacognitive strategies $(M=2.79)$, social strategies $(M=2.70)$, cognitive strategies $(M=2.69)$, memory strategies $(M=2.57)$ and affective strategies $(M=2.48)$. At the tertiary level, students indicated a great preference for compensation strategies $(M=3.04)$, followed by metacognitive strategies $(M=2.90)$, social strategies $(M=2.90)$, cognitive strategies $(M=2.85)$ affective strategies $(M=2.75)$, and memory strategies $(\mathrm{M}=2.74)$.

Table 1. Distribution of language learning strategies by educational levels

\begin{tabular}{lccccccccccccc}
\hline Strategy & \multicolumn{3}{c}{ Elementary } & \multicolumn{4}{c}{ Junior High } & \multicolumn{3}{c}{ Senior High } & \multicolumn{3}{c}{ University } \\
\cline { 2 - 14 } & $\mathrm{N}$ & Mean & SD & N & Mean & SD & N & Mean & SD & N & Mean & SD \\
\hline Memory & 250 & 2.80 & 1.09 & 245 & 2.68 & 0.81 & 249 & 2.57 & 0.77 & 279 & 2.74 & 0.66 \\
Cognitive & 250 & 2.68 & 1.04 & 245 & 2.67 & 0.82 & 249 & 2.69 & 0.77 & 279 & 2.85 & 0.68 \\
Compensation & 250 & 2.60 & 1.04 & 245 & 2.96 & 0.90 & 249 & 2.96 & 0.79 & 279 & 3.04 & 0.70 \\
Metacognitive & 250 & 2.93 & 1.20 & 245 & 2.68 & 0.87 & 249 & 2.79 & 0.90 & 279 & 2.90 & 0.68 \\
Affective & 250 & 2.69 & 1.13 & 245 & 2.50 & 0.90 & 249 & 2.48 & 0.89 & 279 & 2.75 & 0.70 \\
Social & 250 & 2.74 & 1.13 & 245 & 2.68 & 0.93 & 249 & 2.70 & 0.99 & 279 & 2.90 & 0.69 \\
\hline
\end{tabular}

A One-way ANOVA test shows that there is a significant difference between age groups and the use of memory strategies $(\mathrm{F}(3,1018)=3.195, \mathrm{p}=.023)$, cognitive strategies $(\mathrm{F}(3,1018)=2.705, \mathrm{p}=.044)$, comprehension strategies $(\mathrm{F}(3,1018)=13.191, \mathrm{p}=.000)$, metacognitive strategies $(\mathrm{F}(3,1018)=3.972, \mathrm{p}=.008)$, affective strategies $(\mathrm{F}(3,1018)=5.584, \mathrm{p}=.001)$, and social strategies $(\mathrm{F}(3,1018)=3.049, \mathrm{p}=.028)$.

The Scheffe post hoc test (see Table 2 ) shows that elementary school students reported using memory strategies more frequently than senior high school students $(\mathrm{p}=.020)$. Junior, senior high school and university students reported a greater preference for compensation strategies than elementary school students $(p=.000)$. Elementary school students reported a greater use of metacognitive strategies than junior high school students $(p=.014)$. University students reported using metacognitive strategies more often than junior high school students ( $p$ $=.033$ ). University students reported a greater preference for affective strategies than junior and senior high school students $(\mathrm{p}=.013, \mathrm{p}=.004)$. University students reported a greater use of social strategies than junior high school students $(\mathrm{p}=.041)$.

Table 2. Scheffe post-hoc comparison of educational levels and language learning strategies

\begin{tabular}{lccccc}
\hline \multirow{2}{*}{$\begin{array}{l}\text { Language } \\
\text { learning strategy }\end{array}$} & \multicolumn{2}{c}{ Comparison } & $\begin{array}{c}\text { Mean Difference } \\
(\mathrm{I}-\mathrm{J})\end{array}$ & Std. Error & \multirow{2}{*}{ Sig. } \\
\cline { 2 - 3 } Memory & Elementary vs. & Junior & .11440 & .07637 & .807 \\
& Elementary vs. & Senior & $.22401\left(^{*}\right)$ & .07606 & .020 \\
& Elementary vs. & College & .05597 & .07398 & 1.000 \\
& Junior vs. & Senior & .10960 & .07637 & .909 \\
& Junior vs. & College & -.05843 & .07430 & 1.000 \\
& Senior vs. & College & -.16804 & .07398 & .140 \\
\hline Cognitive & Elementary vs. & Junior & .00815 & .07549 & 1.000 \\
& Elementary vs. & Senior & -.01004 & .07518 & 1.000 \\
& Elementary vs. & College & -.16787 & .07313 & .131 \\
& Junior vs. & Senior & -.01819 & .07549 & 1.000 \\
& Junior vs. & College & -.17602 & .07345 & .100 \\
& Senior vs. & College & -.15783 & .07313 & .187 \\
\hline Compensation & Elementary vs. & Junior & $-.36555\left(^{*}\right)$ & .07814 & .000 \\
\hline
\end{tabular}




\begin{tabular}{cccccc}
\hline & Elementary vs. & Senior & $-.35676\left(^{*}\right)$ & .07782 & .000 \\
& Elementary vs. & College & $-.44163\left(^{*}\right)$ & .07570 & .000 \\
Junior vs. & Senior & .00879 & .07814 & 1.000 \\
Junior vs. & College & -.07608 & .07603 & 1.000 \\
& Senior vs. & College & -.08487 & .07570 & 1.000 \\
\hline Elementary vs. & Junior & $\left..25551^{*}\right)$ & .08375 & .014 \\
& Elementary vs. & Senior & .14502 & .08341 & .494 \\
& Elementary vs. & College & .02865 & .08114 & 1.000 \\
Junior vs. & Senior & -.11049 & .08375 & 1.000 \\
Junior vs. & College & $-.22687\left(^{*}\right)$ & .08149 & .033 \\
Senior vs. & College & -.11638 & .08114 & .911 \\
\hline Affective & Elementary vs. & Junior & .18269 & .08258 & .163 \\
Elementary vs. & Senior & .20884 & .08225 & .068 \\
Elementary vs. & College & -.06429 & .08001 & 1.000 \\
Junior vs. & Senior & .02615 & .08258 & 1.000 \\
Junior vs. & College & $-.24698\left(^{*}\right)$ & .08035 & .013 \\
Senior vs. & College & $-.27313\left(^{*}\right)$ & .08001 & .004 \\
\hline Elementary vs. & Junior & .06270 & .08524 & 1.000 \\
Elementary vs. & Senior & .03681 & .08490 & 1.000 \\
Elementary vs. & College & -.16205 & .08258 & .3000 \\
Junior vs. & Senior & -.02589 & .08524 & 1.000 \\
Junior vs. & College & $-.22475\left(^{*}\right)$ & .08294 & .041 \\
Senior vs. & College & -.19886 & .08258 & 1.000 \\
\hline
\end{tabular}

* The mean difference is significant at the .05 level.

\subsection{Research Question 2}

Statistically significant relationships were found to exist between different age groups and the use of memory strategies, compensation strategies, metacognitive strategies, and affective strategies. Specifically, junior, senior high school and university students reported using compensation strategies more frequently than elementary school students $(\mathrm{p}=.000)$. The finding seems to support that as learners become mature, they tend to use compensation strategies help them overcome limitations in existing knowledge, such as guessing the meaning of unknown words while reading or listening, and using gestures in speaking and synonym in writing (Oxford, 1990).

University students used social and affective strategies more frequently than did other age groups. The result indicated that age increase is likely to encourage learners to use strategies with more emphasis on the social and functional strategies. University students often applied social and affective strategies to involve other people in the language learning process, such as clarification, communication with native speakers or higher proficiency learners, cooperating with peers, self-encouragement, anxiety reduction and increasing knowledge of the target language culture (Oxford \& Crookall, 1989; Oxford, 1990a).

In this study, elementary school students reported using memory strategy more frequently than secondary and tertiary students. This finding is consistent with Chesterfield and Chesterfield's study (1985) that children used receptive strategies such as repetition and memorization first. Then they developed strategies permitting them to start and maintain interactions. They developed strategies demonstrating awareness and monitoring of grammatical errors last.

It was surprising to find that elementary school students used metacognitive strategies more frequently than secondary and tertiary students in this study. The finding is contrary to Magowe \& Oliver's (2007) study that 
students at higher levels of education are more independent learners and secondary and tertiary level students preferred metacognitive strategies. One reason for the inconsistency may be the limited number of the participants. The results in this study may not be generalizable to all the Taiwan population.

\section{Conclusion}

This study found that students of different age groups used different strategies. It's consistent with Prokop's (1989) conclusion, "there may be a natural developmental process in second language learning during which students spontaneously change their learning strategies as they learn to cope with the requirements of various learning tasks" (p. 40). Instructors might be able to adjust their teaching practices to meet the developmental needs of students. Since learning strategies can be taught (Bates, 1972), language teachers can help students of different age groups improve their English proficiency by teaching them how to improve their learning strategies. For example, the results showed that secondary and tertiary students in this study did not employ metacognitive strategies so frequently when they learned English. Teachers can integrate learning strategy training into regular language lessons. First, teachers develop students awareness of metacognitive strategies. Then, teachers demonstrate how to use the strategies of setting goals, planning, seeking practice opportunities, self-monitoring and self-evaluation. Next, students apply the strategies they have learned to the learning activities. Students self-evaluate their use of the strategy and its effectiveness for the task. Finally, students can transfer the strategies to new tasks and manage their own studies.

This study employed a quantitative design. Future studies could employ qualitative methodology (e.g. interviews, classroom observations, diary analysis, think-aloud, etc.) to have a deeper examination about the relationship between age and learning strategy use.

\section{References}

Abdolmehdi, R., \& Mohammad, R. (2005). Iranian EFL learners' pattern of language learning strategy use. The Journal of Asia TEFL, 2(1), 103-129.

Bates, E. (1972). Language and context. New York, NY: Academic.

Bialystock, E. (1978). A theoretical model of second language learning. Language Learning, 28(1), 69-83.

Brown, A., \& Palinscar, S. (1982). Including strategic learning from texts by means of informed self-control training. Topics in Learning and Learning Disabilities, 2, 1-17.

Chamot, A. U., \& Kupper, L. (1989). Learning strategies in foreign language instruction. Foreign Language Annuals, 22, 13-24.

Chang, C. Y., Liu, S. C., \& Lee, Y. N. (2008). A study of language learning strategies used by college EFL learners in Taiwan. Ming-dao Journal of General Education, 2, 235-261. http://www.mdu.edu.tw/ ged/other\%20download/bulletin/20070319/11.pdf

Chesterfield, R., \& Chesterfield, K. B. (1985). Natural order in children's use of second language learning strategies. Applied Linguistics, 6(1), 45-59.

Cohen, A. D. (1990). Language learning: Insights for learners, teachers, and researchers. New York, NY: Newbury House.

Devlina, M. (1996). Older and Wiser? A comparison of the learning and study strategies of mature age and younger teacher education students. Higher Education Research \& Development, 15(1), 51-60.

Ellis, R. (1994). The study of second language acquisition. Oxford: Oxford University Press.

Ehrman, M. (1990). Owls and doves: Cognition, personality, and learning success. In J. E. Alatis (Ed.), Linguistics, language teaching, and language acquisition: The interdependence of theory, practice, and research (pp. 413-437). Washington DC: George-town University Press.

Galbraith, V., \& Gardner, R. C. (1988). Individual difference correlates of second-language achievement: An annotated bibliography. London: University of Western Ontario.

Huang, S. C. (1989). Using peer-teaching in high schools in Taiwan (Unpublished master's thesis, The University of Kansas, Lawrence).

Huang, S. C. (1997). Taiwanese senior high school students' EFL learning: Focus on learning strategies and learning beliefs. Ann Arbor, Michigan: UMI Company.

Lan, R., \& Oxford, R. (2003). Language learning strategy profiles of elementary school students in Taiwan. International Review of Applied Linguistics in Language Teaching, 41(4), 339-379. 
http://dx.doi.org/10.1515/iral.2003.016

Lai, Y. C. (2009). Language learning strategy use and English proficiency of university freshmen in Taiwan. TESOL Quarterly, 43(2), 255-280.

Lee, H. (2000). A relationship between English language learning strategies and cloze test. Journal of English Language Teaching, 12(1), 247-270.

Lee, K. R., \& Oxford, R. (2008). Understanding EFL learners' strategy use and strategy awareness. Asian EFL Journal, 10(1), 7-32.

Lessard-Clouston, M. (1997). Language learning strategies: An overview for L2 teachers. Retrieved June 12, 2010, from http://iteslj.org

Liao, Y. F. (2000). A study of Taiwanese junior high school students' EFL learning motivation and learning strategies (Master thesis, National Changhua University).

Li, J., \& Qin, X. (2006). Language learning styles and learning strategies of tertiary-level English learners in China. RELC Journal, 37(1), 67-90. http://dx.doi.org/10.1177/0033688206063175

Liu, M. L. (2004). A study of beliefs about language learning and learning strategies of senior high school students (Unpublished master's thesis, National Kaohsiung Normal University).

Lo, Y. H. G. (1996). Can whole language be applied to teaching English as a foreign language in secondary schools in Taiwan: Problems, challenges, and possibilities (Unpublished master's thesis, Indiana University, Bloomington).

Magowe, J. M., \& Oliver, R. (2007). The relationship between language learning strategies, proficiency, age and self-efficacy beliefs: A study of language learners in Botswana. System, 35, 338-352.

Naiman, N., Frohlich, M., Stern, H., \& Todesco, A. (1978). The good language learner. Toronto: Ontario Institute for Studies in Education, The Modern Language Center.

Nunan, D. (1988). The learner-centered curriculum. Cambridge: Cambridge University Press.

O’Malley, J. M., \& Chamot, A. U. (1985). Learning strategy applications with students of English as a second language. TESOL Quarterly, 19(3), 557-584.

O’Malley, J. M., \& Chamot, A. U. (1990). Learning strategies in second language acquisition. Cambridge: Cambridge University Press.

Oxford, R. (1987). Strategy inventory for language learning. Alexandria, VA: Author.

Oxford, R. (1989). The role of styles and strategies in second language learning. ERIC Digest. (ERIC Document Reproduction Services, No. ED317 087).

Oxford, R. (1990). Language learning strategies: What every teacher should know. New York, NY: Newbury House Publishers.

Oxford, R. (1992). Who are our students? A synthesis of foreign and second language research on individual differences with implications for instructional practice. TESL Canada Journal, 9(2), 30-49.

Oxford, R., \& Ehrman, M. E. (1993). Second language research on individual differences. In W. Grabe (Ed.), Annual Review of Applied Linguistics (pp. 188-205). Cambridge: Cambridge University Press.

Oxford, R., \& Crookall, D. (1989). Language learning strategies: Methods, findings, and instructional issues. Modern Language Journal, 73(4), 404-419.

Oxford, R., \& Nyikos, M. (1989). Variables affecting choice of language learning strategies by university students. Modern Language Journal, 73, 291-300.

Peng, L. (2002). Applying learning style in instructional strategies. Center for Development of Teaching and Learning, 5(7), 1-3.

Prokop, M. (1989). Learning strategies for second language users: An analytical approach with case studies. Lewiston, NY: The Edwin Mellen Press.

Rubin, J. (1981). Study of cognitive progresses in second language learning. Applied Linguistics, 11(2), 117-131.

Scarcella, R. C., \& Oxford, R. L. (1992). The tapestry of language learning: The individual in the communicative classroom. Boston, MA: Heinle.

Skehan, P. (1989). Individual indifferences in second language learning. London, UK: Edward Arnold. 
Wong, F. L., Ammon, P., McLaughlin, B., \& Ammon, M. (1985). Learning English through bilingual instruction. Final report submitted to the National Institute of Education. Berkeley: University of California.

Yang, N. D. (1992). Second language learners' beliefs about language learning and their use of learning strategies: A study of college students of English in Taiwan (Doctoral dissertation, The University of Texas at Austin, Dissertation Abstracts International, 53, 2722A).

\section{Copyrights}

Copyright for this article is retained by the author(s), with first publication rights granted to the journal.

This is an open-access article distributed under the terms and conditions of the Creative Commons Attribution license (http://creativecommons.org/licenses/by/3.0/). 